\title{
Relationship Between Knowledge and Attitude with Implementation of Patient Safety Targets in RSUD Yogyakarta
}

\section{Nur Syarianingsih Syam*, Siti Kurnia Widi Hastuti*}

* Correspondent Author: nur.syam@ikm.uad.ac.id

* Faculty of Human Health Science, Universitas Ahmad Dahlan, Yogyakarta, Indonesia

\section{N D E X I N G}

Keywords:

Target;

Patient Safety;

Knowledge;

Attitudes;

Nurse

\section{Kata kunci:}

Sasaran;

Keselamatan Pasien;

Pengetahuan;

Sikap;

Perawat;

\begin{abstract}
A B S T RA C T
Joint Commission International stipulates the International Patient Safety Goals (IPSG) as one of the points in the hospital's international accreditation assessment. In Indonesia the IPSG target was translated by the hospital accreditation committee (KARS) into 6 patient safety targets (SKP) in the 2012 hospital accreditation guidelines (KARS 2012). Yogyakarta Regional General Hospital (RSUD) is one of the class B public hospitals that have received Akreditasi Paripurna, in this case all working groups including patient safety standards at the hospital have been assessed. However, there are still KTD, KNC, KPC, and KTC in Yogyakarta Hospital. This study aimed to analyze the relationship between attitudes and knowledge with the implementation of patient safety goals by nurses in Yogyakarta Hospital. The study used quantitative research methods with a cross sectional research design. Data retrieval is done by distributing questionnaires related to attitudes and knowledge to 80 nurses with the implementation of patient safety goals, the sampling technique with clustered stratified sampling. Data analysis techniques for quantitative analysis with univariate, bivariate (chi square test). Research results of the relationship between knowledge and implementation of SKP showed that the $p$-value of $\alpha(0.631>0.05)$, means that there is no relationship between nurse knowledge and the implementation of patient safety goals (SKP). The results of the study of attitude relations with SKP Implementation can be seen that the p-value $\alpha(0.045<0.05)$, meaning that there is a relationship between nurse attitudes and the implementation of patient safety goals (SKP).
\end{abstract}

\begin{abstract}
Joint Commission Internasional menetapkan Internastiomal Patiet Safety Goals (IPSG) sebagai salah satu poin dalam penilaian akreditasi internasional rumah sakit. Di Indonesia sasaran IPSG dijabarkan oleh komite akreditasi rumah sakit (KARS) menjadi 6 sasaran keselamatan pasien (SKP) dalam panduan akreditasi rumah sakit 2012 (KARS 2012). Rumah sakit Umum Daerah (RSUD) Yogyakarta merupakan salah satu rumah sakit kelas $B$ milik pemerintah yang telah mendapatkan akreditasi paripurna, dalam hal ini semua kelompok kerja termasuk standar keselamatan pasien di rumah sakit tersebut telah dinilai. Namun, di RSUD Yogyakarta masih terdapat KTD, KNC, KPC, dan KTC. Penelitian ini bertujuan menganalisis hubungan antara sikap dan pengetahuan dengan implementasi sasaran keselamatan pasien oleh perawat di RSUD Yogyakarta. Penelitian menggunakan metode penelitian Kuantitatif dengan rancangan penelitian cross sectional. Pengambilan data dilakukan dengan penyebaran kuesioner terkait sikap dan pengetahuan kepada 80 perawat dengan implementasi sasaran keselamatan pasien, Teknik pengambilan sampel dengan clustered stratified sampling. Teknik analisa data untuk kuantitatif dengan analisi univariate, bivariate (uji chi square). Hasil Penelitian hubungan pengetahuan dan implementasi SKP menunjukka bahwa nilai p-value $\alpha(0,631>0,05)$, berarti tidak ada hubungan pengetahuan perawat dengan implentasi sasaran keselamatan pasien (SKP). Hasil penelitian hubungan sikap dengan Implementasi SKP dapat diketahui bahwa nilai p-value $\alpha(0,045<0,05)$, artinnya ada hubungan sikap perawat dengan implentasi sasaran keselamatan pasien (SKP).
\end{abstract}

(C) 2018 JMMR. All rights reserved

\section{INTRODUCTION}

Patient Safety is the most current, global and high profile issue in hospital services. In 2000 the Institute of Medicine (IOM) in the United States examined that out of 33.6 million inpatients there were 44,000 to 98,000 people died due to medication errors and adverse event medical procedures each year. The publication of the World Health Organization (WHO) in 2004, collecting research numbers in hospitals in various countries such 
as the United States, Britain, Denmark and Australia found an unexpected incidence (KTD) ranging from 3.2$16.6 \%$.

Patient safety is a basic principle of patient service and a critical component of quality management and this is reinforced by the stipulation of the International Patient Safety Goals (IPSG) in the Joint Commission International (JCI) accreditation. Accreditation of hospitals JCI is an international accreditation where the focus is patient safety contained in IPSG, the chapter was developed as an indicator of identification of medical problems that have the potential to cause unexpected events or impacts.

The hospital accreditation committee (KARS) included hospital patient safety into the hospital accreditation assessment component in 2007 which was later updated by including 6 patient safety goals in the 2012 hospital accreditation guidelines which are derived from International Patient Safety Goals (IPSG).

Every hospital must strive to fulfill patient safety goals. The targets of patient safety include achieving the following: accuracy of patient identification; increased effective communication; drug safety enhancements that need to be watched out; the exact location, the right procedure, the right patient operation; reduced risk of infection related to services; risk reduction of patients falling. In applying hospital safety standards, aspects of human resources (HR) have a very important role. Actually, none of the health workers in the hospital in their care have the intention of injuring their patients. But in reality there are always cases of unexpected events (KTD), KNC, KPC and sentinel events in the process of caring for medical services and nursing care both mild to severe events ${ }^{2}$.

Nowadays, data about unexpected events (KTD) in Indonesia, potential injury events (KPC), non-injury events (KTC) especially near miss or near-injury events (KNC) are still difficult to obtain. Based on the results of a survey conducted by Ramsay Health Care Clinical Governance Unit in 2005 in the field of nursing in a private hospital in Indonesia, out of a total sample of 236 nursing staff hospitalized, around 57 people (24\%) made medication errors $\stackrel{3}{-}$.

Factors that influence the achievement of patient safety targets include the attitudes and knowledge of nurses. The attitudes and knowledge of nurses were assessed according to the patient safety system material, it based on JCI and National guidelines along with the Patient Safety Incident Reporting Guidelines (PPIKP). In the scope of patient safety, knowledge of health human resources including nurses is a matter that is related to commitments that are very necessary in an effort to build a patient safety culture ${ }^{4}$.

The Regional General Hospital (RSUD) of Yogyakarta City is a hospital owned by the class B government and has passed the plenary level of the KARS 2012 assessment standard. Based on the results of preliminary studies conducted at the Patient Safety Installation in Yogyakarta City Hospital, information was obtained that all patients in the RSUD of Yogyakarta City has been running since 2014 in the form of a committee and begin in the form of installations in 2015. Regarding cases related to patient safety advice, the following data were obtained for January - November 2016, namely KTD, 9 cases, KNC 44 cases, KTC 10 cases, KPC 1 case. This case data shows that the patient safety target in Yogyakarta City Hospital has not been achieved.

In addition, the data above is still not fully the actual incident data reported. According to preliminary interviews, there were cases that were not reported, such as patients falling under the pretext that this was not a nurse's fault because previously patients had been given education and information on care services, or cases of wrong drug administration but were immediately realized by nurses.

Based on the background, the author aimed to determine the relationship between nurse knowledge and nurse attitudes with the implementation of the Patient Safety Target (SKP) in Yogyakarta City Hospital.

\section{RESEARCH METHOD}

This study used quantitative research methods, with a cross sectional study design. Data collection is done by distributing questionnaires related to nurses' attitudes and knowledge with patient safety goals. The number of nurses involved in this study were 80 people taken using the Slovin formula and carried out evenly on each unit / service installation using cluster random sampling. Data analysis techniques for quantitative analysis with univariate, bivariate (chi square test)

\section{RESULT AND DISCUSSION}

Distribution Nurse According to Range of Age, Gender, and Degree of Education, Knowlegde and Attitudes.

In terms of age, the majority of respondents were at the age of $>34$ are 43 nurses $(53,57 \%)$. The more age, the level of maturity and strength of a person will be more mature in thinking and working7. Nurses of that age are said to be included in the productive age to 
produce good performance. A well performing nurse has great potential to develop.

Table 1. Distribution Information Category of Nurses

\begin{tabular}{|c|c|c|c|c|}
\hline No & Variable & Category & Frequently & $\%$ \\
\hline \multirow[t]{2}{*}{1} & \multirow{2}{*}{ Age } & $<35$ & 37 & 46.25 \\
\hline & & $\geq 34$ & 43 & 53.75 \\
\hline \multirow[t]{2}{*}{2} & \multirow{2}{*}{ Gender } & Female & 60 & 75 \\
\hline & & Male & 20 & 25 \\
\hline \multirow[t]{8}{*}{3} & & Diploma & & \\
\hline & & III & 53 & 66.3 \\
\hline & Level or & Diploma & & \\
\hline & Degree of & IV & 5 & 6.25 \\
\hline & Education of & & & \\
\hline & Nurse & SI Nurse & 4 & 5 \\
\hline & & S1 Nurse & 17 & 21.3 \\
\hline & & $\mathrm{S} 2$ & 1 & 1.3 \\
\hline \multirow[t]{3}{*}{4} & Knowledge & High & 42 & 52 \\
\hline & of Patient & & & \\
\hline & Safety & Low & 38 & 48 \\
\hline \multirow[t]{3}{*}{5} & Attitude Of & Good & 41 & 51.3 \\
\hline & Patient & & & \\
\hline & Safety & $\mathrm{Bad}$ & 39 & 48.8 \\
\hline
\end{tabular}

Professionalism in providing care to clients. Age of 20-25 years is the first period of recognition process in the adult world, a person in this period will begin to seek the place of the world of work and the world of social relations ${ }_{-}^{5}$.

In terms of gender, the majority of respondents, namely 60 nurses $(75 \%)$ were female. There is no difference between women and men in problem solving skills, analytical skills, competitive encouragement, motivation, social ability and ability to increase knowledge. The condition in the hospital shows that the proportion of female nurses is more than that of men is reasonable because very rarely men who have a career as nurses ${ }^{17}$.

Nurses who were respondents to the study, the majority were still educated in Diploma degree are 53 $(66.3 \%)$. As such the skill set that degree nurses obtain is more extensive compared to apprenticeship training, which is said to assist them in finding solutions for intricate patient situations. The higher level of education will be more rational and creative and open in accepting various renewal efforts and can adjust to renewal. The level of education of someone is influential in responding to something that comes from outside ${ }^{17}$.
According to the table, nurses knowledge is a high about 42 (52\%), With the knowledge of understanding it, the nurses are expected to have critical thinking in decision making with regard to his actions. The Lack of knowledge toward a particular object due to lack of the information obtained. In addition to the knowledge about management, the most important to be possessed by the nurse is knowledgeable about the patient safety $\stackrel{6}{-}$ Knowledge can be acquired through learning, with structured education and training.

Nurse knowledge about patient safety is very important to encourage the implementation of the program of patient safety because knowledge is a major factor influencing the behavior and performance of the nurses. Nurses must know the understanding patient safety, the elements that exist in patient safety, patient safety goal, the efforts of patient safety and selfprotection during work. Nurses compliance are how the nurses behavior according with the rule 5 .

According to the table, nurses' attitude is a good about $41(51.3 \%)$. Attitude is a one of other factors predisposing of behavior $\stackrel{6}{-}$. The Cambridge dictionary defines attitude as a feeling or opinion about something or someone, or a way of behaving. Healthcare provider attitudes about organizational factors such as safety climate and morale, work environment factors such as staffing levels and managerial support, team factors such as teamwork and supervision, and staff factors such as overconfidence and being overly self-assured are components of an organization's safety culture $?$. According to psychological experts, attitude is a form of evaluation or feeling reaction. Person's attitude toward an object is feeling supported (favorable) or feelings of support (unfavorable) on the object $\stackrel{8}{\text {. }}$

\section{Relationship between Knowledge and Implementation of Patient Safety}

Based on table 2, the results of the Chi Square statistical test, it can be seen that the p-value $\alpha(0.631>$ $0.05)$, so it can be concluded that $\mathrm{Ha}$ is rejected and Ho is accepted, which means there is no relationship between knowledge of nurse and the implementation of patient safety goals (SKP).

The results of this study are in consist with the research entitled the relationship of the level of nurse knowledge about patient safety in terms of compliance with the implementation of injection drug administration in Surakarta Islamic hospitals ? 
Table 2. Cross Tabulation of Relationship between Knowledge and Implementation of Patient Safety Goals by Nurses in Yogyakarta Public Hospital 2018

\begin{tabular}{ccccccc}
\hline \multirow{3}{*}{ Knowledge } & \multicolumn{4}{c}{ Implementation of SKP } & \multirow{2}{*}{ Total } & \multirow{2}{*}{ P Value } \\
\cline { 2 - 5 } & \multicolumn{2}{c}{ Not Obedient } & \multicolumn{2}{c}{ Obedient } & & \\
\cline { 2 - 5 } & $\mathbf{n}$ & $\mathbf{\%}$ & $\mathbf{N}$ & $\mathbf{\%}$ & $\mathbf{n}$ \\
\hline Low & 13 & 48.15 & 14 & 51.85 & 27.0 & \multirow{2}{*}{0,631} \\
\hline High & 25 & 47.17 & 28 & 52.83 & 53.0 & \\
\hline
\end{tabular}

The results of this study are also in line with another research which is known to have no relationship between the creation of a safety culture and nurses' knowledge. However, from the statistical results there are differences, namely nurses who tend to create a patient safety culture, have a tendency towards low patient safety related knowledge ( $p=0.003, r=, 60.6)$. In addition, the results of research showed that there are still nurses who do not understand the importance of reporting medical errors. The importance of reporting medical errors is due to the nurses' lack of knowledge regarding service errors. The nurse cannot decide whether the incident experienced by the patient is an unexpected event (KNC), the incidence of near injury $(\mathrm{KNC})_{-}^{8}$.

The results of different studies indicate that there is a relationship between the variable knowledge of the implementation of patient safety at the Tahuna Hospital 10. In another study, it was also mentioned that giving information transfer during training can increase nurses' knowledge that can be used in improving patient safety goals ${ }^{11}$. A person's knowledge is closely related to one's actions in fulfilling their obligations, so further education is very important in gaining knowledge $\stackrel{12}{ }$. Knowledge is the main capital in shaping skills and attitudes, with good knowledge individuals will be motivated to improve good behavior. Therefore knowledge that supports skills needs to be provided so that staff can carry out their duties based on theoretical theories that can be accounted for $\stackrel{13}{\text {. }}$.

The fulfillment of patient safety targets according to the achievement indicators used by the hospital is based on the similarity of apperception regarding patient safety. Knowledge of patient safety and nurse attitudes influence the implementation of patient safety programs $\underline{13}$. Knowledge is an important factor in someone making a decision, but not always someone's knowledge can avoid them from undesirable events, for example nurses who have a good level of knowledge, they do not always carry out patient safety properly because all actions to be taken are at risk for errors $\frac{14}{-}$.

Giving knowledge through training has been carried out at Yogyakarta City Hospital, but there has been no monitoring and evaluation from the results of the pretest and posttest that have been conducted. The same result found in research on Queen Hospital Yogyakarta that hospital has train the nurses but the training was not continuously conducted $\stackrel{15}{-}$. The previous research stated that training related to KPRS is important to do periodically as well as the implementation of monitoring and evaluation. The high level of knowledge but is not in line with the implementation of patient safety can be caused because during the training and seminar respondents were less interested, so when receiving the information not interested and the respondent only hears, sees, reads, without absorbing it to be understood 16 . Providing training and seminars can be useful for evaluating programs and standards including standards of nursing care $\frac{17}{}$.

Various studies have linked the lack of knowledge regarding the reporting of medical errors as common barrier. Medical errors reporting system should take priority in accordance with health care providers training and evaluation report. Understanding and identifying reporting errors and barriers to it can help to increase the percentage of reporting medical errors $\stackrel{8}{\text {. }}$

The solution to how health care professionals' knowledge regarding patient safety may be improved could lie training courses. For example the results of other research showed that day courses in patient safety theory, root cause analysis and small group facilitation, significantly improved senior doctors knowledge about patient safety after the course and this knowledge was

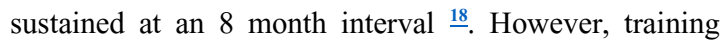
courses are not a stand-alone solution and knowledge of the current status of the patient and the interventions they receive is also a key element in improving safety ${ }^{7}$.

\section{Relationship between Attitudes and Implementation of Patient Safety}

Based on table 3, it can be seen that the p-value $\alpha$ $(0.045<0.05)$, so it can be concluded that Ha is accepted and Ho is rejected, which means there is a relationship between nurse attitudes and the implementation of patient safety goals (SKP). 
Table 3. Cross Tabulation Relationship between Attitudes and Implementation of Patient Safety Goals by Nurses in Yogyakarta Public Hospital 2018

\begin{tabular}{lcccccc}
\hline \multirow{2}{*}{ Attitudes } & \multicolumn{4}{c}{ Implementation of SKP } & \multirow{2}{*}{ Total } & \multirow{2}{*}{ P Value } \\
\cline { 2 - 6 } & \multicolumn{2}{c}{ Not Obey } & \multicolumn{2}{c}{ Obey } & \\
\cline { 2 - 6 } & $\mathrm{n}$ & $\%$ & $\mathrm{~N}$ & $\%$ & $\mathrm{n}$ \\
\hline Bad & 19 & 34.1 & 22 & 65.9 & 41 \\
\hline Good & 18 & 59.0 & 21 & 41.0 & 39 & 0,045 \\
\hline
\end{tabular}

The results of the study are in line with the results of research at Santo Borromeus Hospital, stating that there is a significant relationship between nurses' attitudes and nurse performance in applying patient safety goals $\underline{20}$. The results of research at Santa Anna Kendari Hospital showed the same thing, namely there was a relationship between nurses' attitudes in implementing patient safety $\stackrel{19}{-}$.

Attitude is an evaluative statement on objects, people or events. It is a picture of someone's feelings for something. The attitude of safety culture is the nurse's perspective in carrying out a patient safety culture. Measuring instruments will produce negative attitudes and positive attitudes, negative attitudes are interpreted as low evaluations of existing objects that reflect a person's behavior and positive attitudes and responses or views of nurses to implement safety culture patient $\underline{21}$. Assessment of attitudes is a reliable measure for evaluating the efficacy of patient safety programs.

Attitude is a determinant of behavior. In the form of preparedness for mental preparedness, which is learned in one period of time and organized by experience, and has a certain influence on one's responsiveness to other people, objects, and situations related to it. Attitudes are determined by three components, namely cognitive, affective and behavioral. This situation shows that the attitude of nurses in this case does not end in the formation of a behavior, meaning that the positive attitude possessed by the officer is not always realized in the form of positive behavior. Attitudes as factors that exist in humans and can cause human tendency to act or behave towards the object at hand $\stackrel{22}{=}$.

Based on this research the health care professionals' attitudes towards event reporting were also positive and they agreed that it was an important part of their job, but were still afraid about punitive consequences. In the area regarding safety attitudes, improvements were found when after health care professionals' had received training they had more positive attitudes to patient safety 7. While the attitudes were positive, we may think that at least to some extent everybody is aware of safety issues. But when health care professionals do not actually report or do not report enough it means something wrong is with the system. It is a reflection how the system is working

In other ways, there is a connection in Bloom's behavioral theory which explained that behavior is a function of predisposing factors, namely factors that exist within the individual in which there is an attitude of the individual $\stackrel{22}{2}$. Individual attitudes influence nurse actions in implementing patient safety goals.

Based on the results of the study showed that there is a relationship between attitude and implementation of SKP because attitude is an action, so a good attitude of nurses can make someone obedient to the implementation of SKP, this is due to the willingness and self-awareness of nurses on the implementation of SKP enough so that nurses consider that SKP implementation important to do, so that nurses comply with the implementation of SKP. To improve the patient safety culture, nurses' awareness of the importance of patient safety also needs to be improved $\stackrel{23}{-}$.

Implementation of patient safety goals (SKP) besides being one of the standards in accreditation as well as the occurrence of incidents of patient safety at the hospital will have a detrimental impact on the hospital, staff, and patients, especially as recipients of services. The other impact caused is a decrease in the level of public trust in health services. The low quality or quality of care provided, because patient safety is part of quality ${ }^{4}$. The patient safety culture is an important quality indicator in health care and has been associated with patient outcomes obtained by patients in hospitals $\underline{23}$. Safety must be an important part of the culture of health service organizations and is a major concern for all health care providers $\underline{24}$.

Patient safety must be the first priority of Health care provider. Theoretical grounds should be combined with educational experiences following the development of knowledge, skills and attitudes for effective patient safety. Evaluation of nursing attitude towards the reporting of medical errors is important because attitudes can affect behavior Learning how the system and attitude 
cause errors are the first step in the development process to prevent similar errors in the future.

\section{CONCLUSION}

The research results of the relationship between knowledge and implementation of SKP showed that the $p$-value of $\alpha(0.631>0.05)$, means that there is no relationship between nurse knowledge and the implementation of patient safety goals (SKP). The results of the study of attitude relations with SKP Implementation can be seen that the p-value $\alpha(0.045$ $<0.05$ ), meaning that there is a relationship between nurse attitudes and the implementation of patient safety goals (SKP).

From the results of the research that has been carried out, there are several recommendations that can be submitted to the hospital, namely the process of monitoring the results of education and training related to patient safety material. Conduct a patient safety culture survey to measure nurses' knowledge regarding patient safety.

This study has limitations in terms of the time of data collection and the limitations of informants who experience work rotation in the unit under study

\section{ACKNOWLEDGMENT}

This research was fully facilitated by the Yogyakarta regional public hospital, and funded by DRPM DIKTI, supported by LPPM UAD.

\section{REFERENCE}

1. Departemen Kesehatan RI. Panduan Nasional Keselamatan Pasien Rumah Sakit (Patient Safety). Jakarta: Dpartement Kesehatan Republik Indonesia; 2008.

2. Kementerian Kesehatan. Peraturan Menteri Kesehatan republik Indonesia No. 1691 Tentang Keselamatan Pasien Rumah Sakit. Indonesia; 2011.

3. Dewi GK. Hubungan Antara Pengetahuan Dengan Sikap Patient Safety Perawat Instalasi Rawat Inap di RS Bhayangkara Tingkat I Raden Said Sukanto. Universitas Indonesia; 2010.

4. Cahyono J. SB. Membangun Budaya Keselamatan Pasien Dalam Praktik Kedoktera. Kanisius. Indonesia: Kanisius, Yogyakarta; 2008.

5. Puspita Dewi P. Implementation Analysis Of Effective Communication Guide On Nurses In PKU Muhammadiyah Gamping Hospital. J Medicoeticolegal dan Manaj Rumah Sakit. 2018;7(1):60-8.
6. Qurratul Aini; Muhammad Firdaus. The Influence Of The Knowldge Level And Nurses Atituteds Towards Implementation Of Standard Operating Procedures (SOP) Of Infusion In PKU Muhammadiyah Hospital Bantul. J Medicoeticolegal dan Manaj Rumah Sakit. 2014; Vol 3, No (No 1).

7. Brasaite I. Health Care Professionals Knowledge and Attitudes Regarding Patient Safety and Skills for Safe Patient Care. 2016. 12 p.

8. Safarpour H, Tofighi M, Malekyan L, Bazyar J, Varasteh S, Anvary R. Patient Safety Attitudes, Skills, Knowledge and Barriers Related to Reporting Medical Errors by Nursing Students. Int J Clin Med [Internet]. 2017;08(01):1-11. Available from:

http://www.scirp.org/journal/doi.aspx?DOI=10.423 6/ijcm.2017.81001

9. Novianti R. Hubungan Tingkat Pengetahuan Perawat Tentang Keselamatan Pasien Dengan Kepatuhan Pelaksanaan Prinsip Pemberian Obat Injeksi Di Rumah Sakit Islam Surakarta.

10. Aprilia S. Faktor-faktor yang mempengaruhi perawat dalam penerapan ipsg (. Fkm-Universitas Indones. 2011;

11. Pambudi YD wahyu; ASDDFY. Faktor-Faktor Yang Mempengaruhi Perawat Dalam penerapan 6 SKP (Sasaran Keselamatan Pasien) Pada Akreditasi JCI di Ruang Rawat Inap RS Panti Waluya Malang. Nurs News (Meriden). 2018;3(1):729-47.

12. Darliana Devi. Hubungan Pengetahuan Perawat Dengan Upaya Penerapan Patient Safety di Ruang Rawat Inap Rumah Sakit Umum Daerah DR. Zainoel Abidin Banda Aceh. Idea Nurs J. 2016;VII(1):45-6.

13. Soekijo Notoatmodjo. Manajemen Sumber Daya Manusia. Jakarta: PT. Rineka Cipta; 2009.

14. Ariyani. Program Patient Safety Di Instalasi Perawatan Intensif RSUD DR Moewardi Surakarta Tahun 2008. Universitas Diponegoro; 2009.

15. Hamel RS. Hubungan Pengetahuan Dan Sikap Perawat Dengan Pelaksanaan Keselamatan Pasien (Patient Safety) di Ruang Rawat Inap RSUD Liun Kendage Tahuna. ejournal keperawatan (e-Kp). 2013;1(1).

16. Harsiwi T, Insani N, Sundari S. Analysis of Patient Safety Implementation by Nurses in Queen Latifa Hospital of Yogyakarta , Indonesia. Int J Sci Res Publ [Internet]. 2017;7(8):612-6. Available from: www.ijsrp.org 
17. Harus BD. Pengetahuan Perawat tentang Keselamatan Pasien dengan Pelaksanaan Prosedur Keselamatan Pasien Rumah Sakit (KPRS) Di Rumah Sakit Panti aluya Sawahan Malang. J CARE. 2015;3(1):25-32.

18. Mudayana AA. Peran Aspek Etika Tenaga Medis dalam Penerapan Budaya Keselamatan Pasien di Rumah Sakit. Supplemen Maj Kedokt Andalas. 2014;37:69-74.

19. Ahmed M, Arora S, Baker P, Hayden J, Vincent C, Sevdalis N. Building capacity and capability for patient safety education: A train-the-trainers programme for senior doctors. BMJ Qual Saf. 2013;22(8):618-25.

20. Mawansyah T, Asfian P, Saptaputra S. Hubungan Pengetahuan Sikap Dan Motivasi Kerja Perawat Dengan Pelaksanaan Patient Safety Di Rumah Sakit Santa Anna Kendari. J Ilm Kesehat Masy. 2017;2(6):1-8.

21. Simorangkir DS, Saragih SG, Saptiningsih M. Dengan Kinerja Perawat Dalam Penerapan Sasaran Keselamatan Pasien. 2014; Available from: http://ejournal.stikesborromeus.ac.id/file/6-9.pdf

22. Budihardjo A. Pentingnya Safety Culture Di Rumah Sakit: Upaya Meminimalkan Adverse Events. Integritas - J Manaj Bisnis. 2008;1(Mei):53.

23. James L. Gibson J, M. Ivancevich JHD. Organisasi : Perilaku, Struktur, Proses. Jakarta: Erlangga; 1997.

24. Soekijo Notoatmodjo. Ilmu Perilaku Kesehatan. Jakarta: Rineka Cipta; 2014.

25. Najihah. Budaya Keselamatan Pasien Dan Insiden Keselamatan Pasien Di Rumah Sakit: Literature Review. J Islam Nurs. 2018;3:1-8.

26. Kiyancicek Z, Dedeli O, Yildiz E, Senakin G. A Survey: Health Professionals 'Attitude towards Patient Rights and Patient Safety. Asian J Pharm Nurs Med Sci. 2014;02(01):1-8. 